\title{
Use of Mortgage-Investment Analysis to Study the Behavior of the Population in the Residential Real Estate Market in the City of Kazan
}

\author{
Nail M. Gabdullin*1, Igor A. Kirshin ${ }^{2}$, Linar G. Ibragimov ${ }^{3}$ \\ ${ }^{1,2}$ Kazan Federal University, Institute of Management, Economy and Finance, \\ ${ }^{3}$ The Kazan branch of the Federal State "The Russian State University of Justice" (the city of Kazan), \\ Email:nail56@yandex.ru,,kia1125@mail.ru, linarass@yandex.ru, \\ Contact: 8-903-305-22-61, 8-917-391-93-36, 8-927-033-72-99
}

Received: 21st October 2017 Accepted: 16th November 2017, Published: 31st December 2017

\begin{abstract}
The study considers the issues of making a decision on investing in residential real estate. The investment efficiency was assessed using and without using borrowed funds at different rates of rent growth. In the course of the mortgage market research, the preponderance of the offer of loans with an annuity repayment method was found.

The necessity of using discounting instead of capitalization in mortgage-investment analysis is substantiated. This is due to instability in the cash flows of owners. There may be cases of negative cash flows during the initial stages of investing in real estate with mortgage lending, which are covered by the net cash flow of subsequent stages. It is proved that the expectation by the population of a high level of inflation in the real estate rental market, which influences the price of real estate, facilitates the implementation of real estate transactions.

However, the investment evaluation model based on the capitalization formula does not allow this decision to explain, since it assumes the stability of cash flows in time.

Debt and equity are considered as sources of capital formation when investing. The practical importance of this study is represented by the analysis of the effectiveness of differentiated and annuity methods for repayment of a loan which are used by the leading subjects of mortgage lending: JSC Gazprombank and PJSC Sberbank.

In the course of the study, a detailed analysis of the dynamics of rental price growth and prices of real estate objects was made using the example of a oneroom apartment for 2009-2017. On the basis of the analysis, the interrelation of price dynamics is revealed, the feature of which is the existence of an annual lag between the growth of rental prices and the growth of prices for residential real estate.
\end{abstract}

Keywords: Rent, Mortgage, Internal Rate of Return, Cash Flows, Forecasting.

\section{Introduction}

Residential real estate plays a significant role in ensuring the quality of life of the population and in some cases is also dominant in the definition of consumer behavior. The lack of opportunities to purchase real estate and / or its low quality significantly limits the opportunities for investing in human capital. The level of housing provision for Russians lags far behind the level of developed countries and is a significant limitation of the quality of economic growth.

At the same time, the attitude of the population towards their housing creates serious problems in the labor market. Russians are not ready to part with their homes and migrate to look for promising work, preferring to look for a job in a geographically close neighborhood. Moving is carried out as a last resort. For many Russians, housing is more important than a workplace. Provision of housing for the population is possible in two areas: purchase and sale, and lease. Purchase and sale is possible at the expense of the buyer's funds or at the expense of the buyer's funds with the involvement of bank lending. It is necessary to improve all areas of financing transactions on purchase and sale of residential real estate in order to comply with the condition of the balance of the residential real estate market.

From a financial point of view, buying an apartment or a house is a significant investment for most citizens. Risks associated with the acquisition can create significant difficulties for a buyer. Potential losses are possible because of the complexity of the creation and functioning of real estate and the turnover of rights to it.

\section{Materials and Methods}

Evaluation of investment efficiency is the comparison of income generated by real estate with the value of capital invested in it, taking into account different time periods of investment and obtaining cash flows. Temporary mismatch of cash flows and investments requires bringing their value to a single period.

Introduction to the evaluation model of borrowed capital complicates the model by replacing the borrowed capital with own capital in the capital structure. There are special features of the distribution of the cash flow that falls on all capital and equity (down payment). The difference in profitability for the entire invested capital and profitability for equity is determined by the effect of the financial leverage.

Therefore, we proposed the basic model of investment evaluation of real estate based on the cash flows presented in Formula 1 [6]. Further analysis suggests a modification of this model based on the replacement of capitalization for discounting. 
MP,

$$
\mathrm{V}=\mathrm{PWAF} *(\mathrm{NOI}-\mathrm{DS})+\mathrm{PWF} *(\mathrm{RP}-\mathrm{OS})+
$$

Where

$\mathrm{V}$ is the intrinsic value of the property,

PWAF is a factor of the present value of an annuity at the rate of return on equity,

NOI - net current operating income,

DS - debt service,

PWF - the factor of the current cost of reversion at the rate of return on equity,

$\mathrm{RP}$ - the resale price of the property,

OS - the balance of the mortgage debt for

resale,

MP - the amount of a mortgage credit.

To make a decision on buying (investing) in real estate, it is necessary that the value of the intrinsic value of the real estate with the required return on investment in equity exceeds the cost of the offer of this real estate item. Otherwise, the investment will not provide the required return on equity, that is, this investor has more attractive alternatives compared to this real estate item [7].

At the same time, substituting the value requested by the seller for $\mathrm{V}$ (the intrinsic value of real estate) in formula (1) and solving equation (1) with respect to $Y$ (return on equity) in PWAT and PWF, we obtain a representation of $\mathrm{Y}$ in the form of an internal rate of return (IRR).

\section{Results and Discussion}

Let's consider the above model of investment and mortgage analysis on a specific example. Let's consider in the capacity of an investment object a one-room apartment purchased for the purpose of subsequent renting out. This investment option is of the greatest interest, since it has low entrance barriers to capital. At the same time, this is the most popular option in terms of rent.

As of January 15, 2017, the cost of an average oneroom apartment in the city of Kazan was 2,500,000 rubles. You need cash to purchase an apartment. The initial contribution (equity) in our case is $15 \%$, that is, 375,000 rubles. The apartment is purchased on the secondary market; the term of credit is 30 years, since with a shorter period the monthly payments are more significant. An annuity payment method is chosen, since it is the most common. The study of banks showed that only JSC "Gazprombank" in Kazan offers differentiated payments.

The terms of the mortgage credit in PJSC "Sberbank" are presented in Table 1. Based on the data, the monthly costs of debt servicing $\left(\mathrm{DS}_{\mathrm{m}}\right)$ are 23,506.74 rubles. The annual payment $\left(\mathrm{DS}_{\mathrm{y}}\right)$ is $282,080.88$ rubles.

Table. 1 Terms of Credit under the Annuity Loan Repayment Method in PJSC "Sberbank" [2]

\begin{tabular}{|l|l|l|l|}
\hline Amount of Credit: & 2125000 rubles & Maximum Monthly Payment & 23506,74 \\
\hline Duration: & 360 months & End Date of Payments: & 01.2047 \\
\hline Payment Start Date: & 02.2017 & Over Payment Amount: & $6,337,426$ rubles. \\
\hline Rate: & $13 \%$ & & \\
\hline
\end{tabular}

Lease payment for a one-room apartment for January 2017 was 14,171 rubles per month. An analysis of the growth in rental prices was made to determine profitability. This indicator can be adopted as NOI. Annual NOI is 170052 rubles.

With this financing option, there is a situation of exceeding DS over NOI. This indicates that the value (NOI-DS) will be negative and equal to minus $112,028.88$ rubles. In other words, the owner will be short of the collected rent to cover credit payments.

A negative value (NOI-DS) makes the use of the evaluation model presented in formula (1) incorrect, as this understates the intrinsic value of real estate and leads it to the negative zone. The role (NOI-DS) in the structure of the value of real estate is of paramount importance, especially with long-term ownership of real estate.

A negative value (NOI-DS) indicates the preferences of the lease versus the use of buying an apartment using mortgage lending. It turns out that it is preferable for the investor to rent an apartment for 30 years and save money. As a result of this savings behavior, by the end of 30 years the savings will amount to $3,360,866.4$ rubles.
The inefficiency of using mortgage lending is determined by the applied model of capitalization. The use of inflationary adjustment of the cash flow allows us to justify the effectiveness of attracting a mortgage credit. The current cash flow model for an owner (NOI-DS) uses a capitalization method that requires perpetuity and annuity. The method of capitalization cannot be used since payments (NOI-DS) are not permanent.

Investors buying apartments using mortgage lending hope for NOI growth and, accordingly, growth of the difference between NOI and DS, and future positive NOI-DS values will compensate the initial contribution and costs incurred during the periods of negative NOIDS.

For such an investor, it is inappropriate to use models with capitalization, but a model with discounting should be used. However, it is said only about capitalization in the scientific literature devoted to real estate evaluation.

The use of the assumption on rising prices for residential property in the model raises many questions in the field of forecasting. Calculation of return on investment depends on this assumption. The investor which is optimistic about the rise in property prices and 
rental rates will invest. That potential market actorthat assumes low growth potential will refrain from investing [1].

Price forecasting is impossible with accuracy to a ruble, but it is possible to determine trends within the limits of possible deviations of actual prices. For forecasting it is necessary to consider the dynamics of price development in the real estate market. Table 2 shows the data of the price index in the primary and secondary housing markets and the dynamics of consumer prices.

Table 2 Dynamics of the Cost of Rent and Prices of 1 Square Meter of Housing in 2009-2017 [8,9]

\begin{tabular}{|c|c|c|c|c|c|c|c|c|c|}
\hline & 2009 & 2010 & 2011 & 2012 & 2013 & 2014 & 2015 & 2016 & 2017 \\
\hline $\begin{array}{l}\text { The average cost of } \\
\text { a monthly rent of } \\
\text { an apartment }\end{array}$ & 6781 & 8566 & 11484 & 12857 & 14700 & 13843 & 14385 & 14260 & 15722 \\
\hline $\begin{array}{l}\text { The average price } \\
\text { of } 1 \text { square meter of } \\
\text { an apartment }\end{array}$ & 40832 & 41253 & 45,605 & 55,855 & 58002 & 66008 & 62095 & 67019 & 65817 \\
\hline Rate of rentgrowth & & 1.26 & 1.34 & 1.12 & 1.14 & 0.94 & 1.04 & 0.99 & 1.10 \\
\hline $\begin{array}{l}\text { Rate of } \begin{array}{l}\text { price } \\
\text { growth per } 1 \text { square } \\
\text { meter }\end{array} \\
\end{array}$ & & 1.01 & 1.11 & 1.22 & 1.04 & 1.14 & 0.94 & 1.08 & 0.98 \\
\hline $\begin{array}{l}\text { The multiplier (the } \\
\text { average cost of a } \\
\text { monthly rent / price } \\
\text { of } 1 \text { square meter of } \\
\text { an apartment) }\end{array}$ & 0.17 & 0.21 & 0.25 & 0.23 & 0.25 & 0.21 & 0.23 & 0.21 & 0.24 \\
\hline
\end{tabular}

A quick look at the dynamics of prices allows us to distinguish two periods. In 2009-2014 years a stage of high inflationary dynamics was observed (Tab. 2). The average annual growth rate of prices was more than 15\%. In 2014-2017 there was a period of deflation and / or a weak price increase. An analysis of the growth rates of the average monthly rent and the cost per square meter allows us to speak of the existence of a lag. After the high dynamics of growth in the value of rent in a year there was a significant increase in prices for apartments ${ }^{1}[1]$. This relationship is confirmed by the stable value of the multiplier which since 2010 varies in a narrow range from $21 \%$ to $25 \%$.

The rate was adopted at $15 \%$, moderate value - $10 \%$, and pessimistic - $6 \%$, in the capacity of an optimistic scenario of the rent growth rate.

In reality, there is a contradiction between the investment expectations of the population and government statements about the need to reduce inflation. On the one hand, reducing inflation leads to a decrease in investment efficiency.
On the other hand, lower inflation will lead to lower interest rates on the credit, which will reduce mortgage payments due to refinancing.

In any case, investors will make purchases based on their own ideas about the growth in the cost of rent.

Let's consider the annual cash flow from the lease and payments on the mortgage (Fig. 1). Let's will demonstrate when the investments begin to bring positive cash flows to equity.

At the initial stages after buying an apartment using a mortgage credit, there is an excess of mortgage payments over the rent (net cash flow for the owner). This phenomenon can be considered from the point of view of the investor as a stage of pre-investment in the real estate

${ }^{1}$ Prices to purchase and rent real estate in the city of

Kazan. [Digitalsource ] Access mode:

http://www.rosrealt.ru/, free 


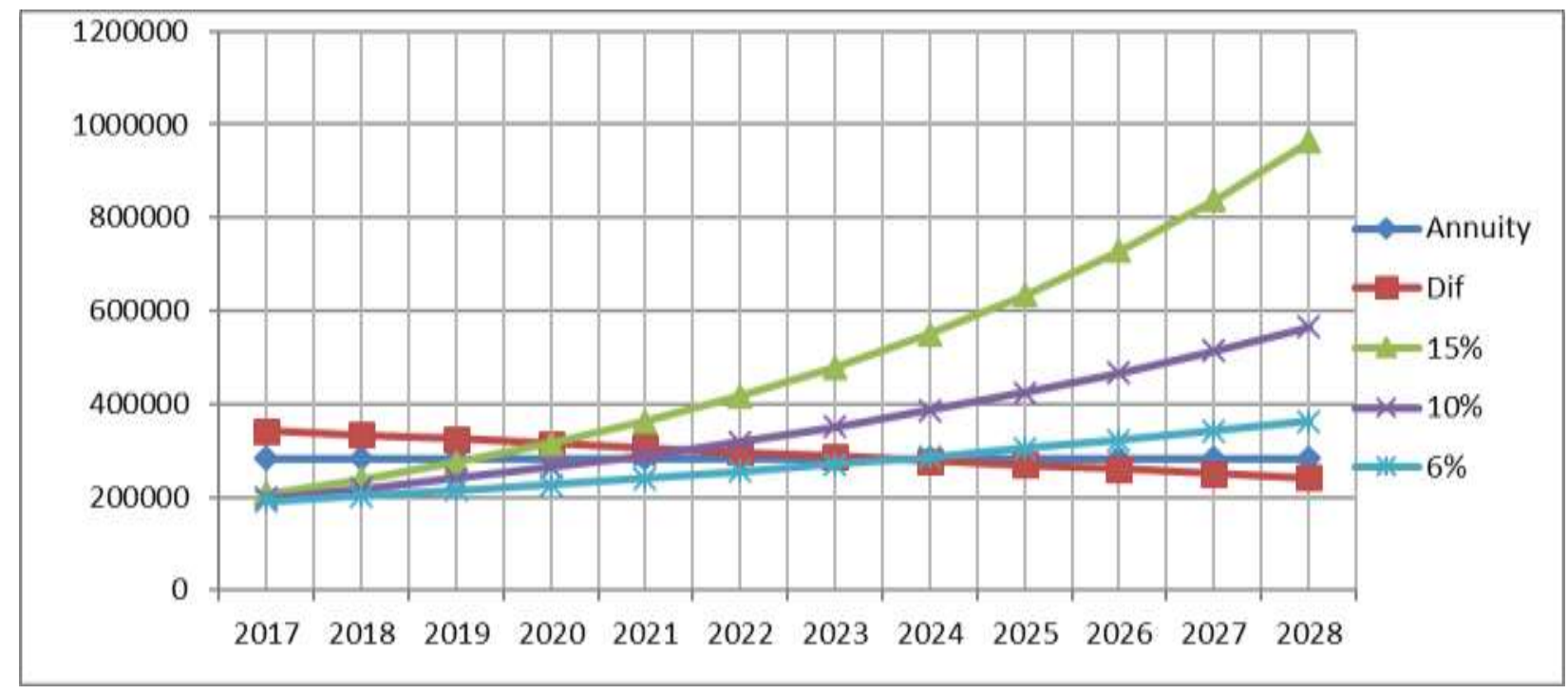

Annuity - Annuity payment

Dif - Differential payment

Fig. 1. Forecasted Annual Cash Flows from the Rent of an Apartment at 6\%, 10\%, 15\% Growth in Payment Rate and Mortgage Payments for Annuity and Differentiated Payments in 2017-2028. (rubles) [2,3]

An investor makes an initial contribution (equity) and makes payment of the missing amount in excess of the collected rent to pay the credit at the initial stage in the hope that future positive cash flows to equity will provide the required level of return.

At a rate of rent growth in $15 \%$ a year the increase investment stage comes to an end in 2018 at annuity payments, and in 2019 at the differentiated payments. At a growth rate of $10 \%$ per annum, the pre-investment period will end in 2020 to annuity and differentiated payments. At a growth rate of $6 \%$ per annum, the preinvestment period will end in 2021 with annuity and differentiated payments.

The efficiency calculations are given in Tables 3 and 4.

Table. 3 Internal Rate of Return at the use of Mortgage Lending

\begin{tabular}{|l|l|l|l|}
\hline Rate of Rent Growth & $15 \%$ & $10 \%$ & $6 \%$ \\
\hline IRR & $33 \%$ & $22 \%$ & $12 \%$ \\
\hline
\end{tabular}

Table 4 Internal Rate of Return using Own Funds

\begin{tabular}{|l|l|l|l|}
\hline Rate of Rent Growth & $15 \%$ & $10 \%$ & $6 \%$ \\
\hline IRR & $24 \%$ & $18 \%$ & $14 \%$ \\
\hline
\end{tabular}

Comparison of Tables 3 and 4 shows that the use of a mortgage credit at a rent growth of $15 \%$ and $10 \%$ is advisable and at $6 \%$ rent growth it is unprofitable. The effect of the financial lever raises the profitability of investments at a $15 \%$ increase in rents from $24 \%$ to $33 \%$ (that is, the effect of the financial leverage is $9 \%$ ), with a $10 \%$ rise in rents from $18 \%$ to $22 \%$ (i.e., the leverage effect is $4 \%$ ). With a $6 \%$ increase in rent, the return on investment in residential real estate is reduced from $14 \%$ to $12 \%$ (that is, the effect of the financial leverage is negative and amounts to $2 \%$ ).

\section{Summary}

The above facts show the following features of the real estate market of Kazan. The average annual growth rate of rent and real estate value in the pre-crisis period is over $15 \%$ per annum. Preserving this dynamic will ensure a high return on investment with the use of own funds, and an increase in profitability when using borrowed funds through the effect of financial leverage. At the same time, the drop in growth rates to 
$6 \%$ will lead to a negative effect of the financial leverage.

\section{Conclusion}

A potentially high level of profitability stimulates the population to view real estate investments as a way of saving, especially against the depreciation of the national currency. The growth of panic about the loss of purchasing power by the national currency led to an increased demand for goods, including real estate. This shows that the population is not inclined to trust the Russian currency because of high inflation and historical memory of the monetary policy of the 90 s of last century.

Economic agents prefer to borrow, not save, taking into account the possible economic instability. As calculations show, the return on investment can reach up to $33 \%$, this is 3-4 times higher than the yield of deposits. The choice of buying a property using mortgage lending is more preferable than placing resources on a deposit. This economic behavior leads to an imbalance in the financial system, creates serious restrictions on economic growth and increases investment risks.

\section{Acknowledgement}

The work is carried out according to the Russian Government Program of Competitive Growth of Kazan Federal University.

\section{References}

[1] Case, K., Shiller, R. (1990) Forecasting prices and excess returns in the housing market // Journal of the American Real Estate and Urban Economics Association 18, 253-273.
[2] Mortgage Calculator URL: http://sberbank.ru/nizhnynovgorod// person / credits / home / buying_complete_house/?utm_source = yandex.b\&utm_medium = context \&utm_term = sberbank_ipoteka\&utm_campaign = Ipoteka, free. Accessed date 07/10/2017.

[3] Mortgage calculator URL: http://www.gazprombank.ru/, free. Accessed date 10.07.2017.

[4] Di Pasquale, D., Wheaton, WC(1994)Housing market dynamics and the future of housing prices // Journal of Urban Economics 35, 1-27.

[5] Juan Ayuso, Fernando Restoy (2006) House prices and rents: An equilibrium equilibrium pricing approach. Journal of Empirical Finance 13 371-388.

[6] Mortgage-investment analysis: Textbook / S.A. Baronin, V.S. Kazeikin, I.V. Popova; Under the general editorship of S.A. Baronin. - M .: SRC INFRAM, 2013. - 176c.

[7] N. Gabdullin, I. Kirshin, L. Vafin (2016) // Ensuring the effectiveness of the privatization of stateowned companies in the conditions of instability of the financial markets (under the example of OJSC "Oil company "Rosneft") // Academy of Strategic Management Journal Volume 15, Special Issue 4, 2431.

[8] Public interactive schedule of prices in the secondary real estate market of Russian cities URL: http://realtymarket.ru/ Accessed date 06/10/2017.

[9] Property and rental prices in Kazan URL:http://www.rosrealt.ru/, free access. Accessed date $07 / 15 / 2017$.

[10] Yong Qiang Chu, Tien Foo Sing (2007) Optimal Timing of Real Estate Investment under Asymmetric Duopoly // Real Estate Finan Econ 34: 327-345. 